\title{
PARTIAL VP2 SEQUENCING OF CANINE PARVOVIRUS (CPV) STRAINS CIRCULATING IN THE STATE OF RIO DE JANEIRO, BRAZIL: DETECTION OF THE NEW VARIANT CPV-2c
}

\author{
Castro, T.X.* ${ }^{1}$; Costa, E.M ${ }^{1}$.; Leite, J.P.G. ${ }^{2}$; Labarthe, N.V. ${ }^{3}$; Cubel Garcia, R.C.N. ${ }^{1}$ \\ ${ }^{1}$ Departamento de Microbiologia e Parasitologia, Instituto Biomédico, Universidade Federal Fluminense, Niterói, RJ, Brasil; \\ ${ }^{2}$ Laboratorio de Virologia Comparada e Ambiental, Instituto Oswaldo Cruz, Manguinhos, RJ, Brasil; ${ }^{3}$ Programa de \\ Biodiversidade e Saúde, Fundação Oswaldo Cruz, Rio de Janeiro, RJ, Brasil.
}

Submitted: October 28, 2009; Returned to authors for corrections: January 20, 2010; Approved: April 26, 2010.

\begin{abstract}
Canine parvovirus (CPV) is the most important enteric virus for dogs and it seems to be undergoing continuous evolution, generating new genetic and antigenic variants throughout the world. The aim of this study was to analyze the distribution of CPV variants from 1995 to 2009 and to investigate the circulation of the new variant CPV-2c in Rio de Janeiro, Brazil. In addition, the clinical features of CPV infection were also reported. After CPV laboratorial confirmation by HA/HI and PCR, thirty-two fecal samples were analyzed by sequencing a 583-bp fragment of the VP2 gene. One sample, collected in 2008 was typed as the new type CPV-2c. All samples from 1995 to 2003 were identified as "new CPV-2a". From 2004 to 2006, both "new CPV-2a" and CPV-2b were observed. From 2006 to 2009, most of the samples were characterized as CPV-2b. The classical signs of CPV enteritis were observed in 16/18 CPV-2a and 5/13 CPV-2b infected puppies. These results show that continuous epidemiological surveillance of CPV strain distribution is essential for studying the patterns of CPV-2a and $2 b$ spread and for determining whether the new variant CPV-2c has become permanently established in Brazilian canine population.
\end{abstract}

Key words: CPV-2c; Sequence analysis; Enteritis; Rio de Janeiro; Brazil

\section{INTRODUCTION}

Since its emergence in the late 1970s, canine parvovirus (CPV) has become one of the most common viruses to cause acute enteric clinical signs (such as vomiting, anorexia, lethargy and diarrhea, with or without melena) in young dogs up to 6 months old worldwide, despite of vaccination program $(12,15)$.

Soon after the appearance of CPV-2, new antigenic types, termed CPV-2a and 2b, emerged in 1979 and 1984, respectively, and replaced the original CPV-2 worldwide (21).
CPV-2a viruses differ from CPV-2 by amino acid (aa) changes in the capsid protein (VP2) at positions 87 (Met $\rightarrow$ Leu), 300 (Gly $\rightarrow$ Ala), 305 (Tyr $\rightarrow$ Asp), and 555 (Val $\rightarrow$ Ile), while CPV-2b differs from CPV-2a at two aa positions, 426 (Asn $\rightarrow$ Asp) and 555 (Ile $\rightarrow$ Val) $(21,26)$.

A CPV-2a variant with a nucleotide change at position 4449 (residue 555) was first reported in 2001 (2, 17). This new variant has a Val replacing Ile-555, and some authors refer to these viruses as "new CPV-2a". The residue 555 is located on a minor antigenic site, and the mutation of Ile-555 to Val represents a reversion of the sequence to the original type

\footnotetext{
*Corresponding Author. Mailing address: Departamento de Microbiologia e Parasitologia, Instituto Biomédico, Universidade Federal Fluminense, Rua Prof. Ernani Pires de Melo, 101 cep 24210-130 - Niterói, Rio de Janeiro, Brazil.; Tel 5521 2629-2432 Fax 5521 2629-2432.; E-mail: txcastro@ yahoo.com.br
} 
CPV-2 (2, 16). With the subsequent introduction and spread of the "new 2 a variant", the Ile-555 CPV-2a has not been detected in the field (10).

In the early 2000's a novel CPV mutant with an aa substitution at position 426 (Asp $\rightarrow$ Glu), located at the major antigenic region over the 3 -fold spike of the CPV capsid, emerged in Italy. This new variant, called CPV-2c, differs from CPV-2b by only one nucleotide $(\mathrm{nt})$ change $(\mathrm{T} \rightarrow \mathrm{A})$ at position 4064 (2). At present, CPV-2c is broadly distributed in Italy (16), and has also been found in Spain (8), Germany, the United Kingdom (9), the United States (13), Australia (17), and Portugal (27). Although the first reports seemed to show a low pathogenicity for $\mathrm{CPV}-2 \mathrm{c}$, experimental data and field observations now indicate that a more severe clinical course with higher mortality rates is associated with $\mathrm{CPV}-2 \mathrm{c}$ infection (10).

This variant has already been detected in South America, specifically in Argentina (3) and Uruguay (23), from stool samples of hemorrhagic enteritis in dogs. This new variant was also recently found in fecal samples from diarrheic dogs from the Southern region of Brazil (24).

In the state of Rio de Janeiro, Southeastern Brazil, previous reports have shown that $\mathrm{CPV}$ is responsible for approximately $46 \%$ of the enteritis cases in puppies $(4,6,7)$. As CPV appears to be undergoing continuous evolution, the main objective of this study was to monitor the distribution of CPV variants in Rio de Janeiro. In addition, the clinical features associated with the different variants were also investigated.

\section{MATERIALS AND METHODS}

A total of 32 fecal samples collected from unvaccinated puppies (16 females and 16 males) less than nine months old presenting diarrhea were analyzed. CPV diagnosis were confirmed by hemagglutination/hemagglutination-inhibiton (HA/HI) tests (7) and polymerase chain reaction assay (PCR) by using the set of primers P2ab, located at nt 3025-3045 and 3685-3706 (within VP2 gene) that detects the new CPV types $(5,25)$.
These samples were collected during a 14-year period (May 1995 to January 2009), and information regarding age, breed, and clinical findings was obtained from the veterinarians' records. Sixteen samples were collected from mix-breed puppies and 16 from purebred: Toy Poodle $(n=2)$, German Shepherd ( $n=3)$, Cocker Spaniel $(n=3)$, American Pit Bull Terrier $(n=2)$, Labrador Retriever $(n=2)$, Yorkshire Terrier $(\mathrm{n}=1)$, Dachshund $(\mathrm{n}=2)$, and Doberman Pinscher $(\mathrm{n}=1)$.

For sequence analysis, viral DNA was extracted from a $10 \%(w / v)$ fecal suspension in Tris- $\mathrm{Ca}^{2+}(5)$. PCR with the 555For/555Rev primers was performed to amplify the $583 \mathrm{bp}$ fragment of the VP2 gene, which encodes the two informative aa (426 and 555) (2). The PCR products were purified using the QIAQuick® PCR purification kit $\left(\right.$ QIAGEN $^{\mathrm{TM}}$, Valencia, CA, USA) and subjected to direct sequencing using the BigDye terminator® v1.1 Cycle Sequencing kit (Applied Biosystems, CA, USA) (20). Alignments and sequence analysis were performed using the BioEdit Sequence Alignment Editor 7.0.1 (http://mbio.ncsu.edu/BioEdit/bioedit. html), and the sequences were compared with those available from GenBank (Table 1). All of the sequences generated in this study were deposited in GenBank (accession numbers: FJ977046-FJ977077).

DNA extracted from commercially available vaccines currently used in Brazil: Vanguard®, Pfizer (CPV-2) and Duramune ${ }^{\circledR}$ Max5, FortDodge (CPV-2b) were also submitted to sequence analysis and used as positive control. DNA extrated from Milli-Q water was used as negative control.

\section{RESULTS}

For CPV typing, the differences in aa 426 (nt 4062-64) were analyzed by sequencing (Table 1). One sample revealed the presence of a GAA codon at position 426 of the VP2 protein. This triplet codes for Glutamate and indicates that this strain is the new type 2c (Glu-426) (Table 1), and it was confirmed by three independent sequencing reactions. The alignment of this sequence with other type 2c sequence fragments from South America showed a $100 \%$ aa identity (Table 1). 
Table 1: Nucleotide and amino acid differences in 583 bp amplicon of the gene of VP2 sequences of 32 CPV strains from the State of Rio de Janeiro, Brazil during 1995-2009.

\begin{tabular}{|c|c|c|c|c|c|c|c|}
\hline \multicolumn{2}{|c|}{$\begin{array}{r}\text { Strains from GenBank } \\
\text { Year }\end{array}$} & Type & $\begin{array}{c}426 \\
(\text { nt 4062) }\end{array}$ & $\begin{array}{c}440 \\
(\text { nt } 4104)\end{array}$ & $\begin{array}{c}555 \\
(\text { nt 4449) }\end{array}$ & $\begin{array}{c}574 \\
(n t 4508)\end{array}$ & Clinical signs \\
\hline M38245 (EUA) & 1978 & $\mathrm{CPV}-2$ & AAT (Asn) & - & GTA (Val) & A & \\
\hline M24000 (EUA) & 1983 & CPV-2a & AAT (Asn) & - & ATA (Ile) & A & \\
\hline DQ340434 (BR) & 2007 & New CPV-2a & AAT (Asn) & - & GTA (Val) & A & \\
\hline FJ236068 (BR) & 2008 & CPV-2b & GAT (Asp) & - & GTA (Val) & $\mathrm{A}$ & \\
\hline EF375482 (URU) & 2007 & CPV-2c & GAA (Glu) & $\mathrm{A}$ & GTA (Val) & A & \\
\hline FJ349322 (ARG) & 2008 & CPV-2c & GAA (Glu) & A & GTA (Val) & - & \\
\hline EU797727(BR) & 2008 & CPV-2c & GAA (Glu) & A & GTA (Val) & A & \\
\hline RJ004/95 & 1995 & New CPV-2a & AAT (Asn) & - & GTA (Val) & G & V, A, L, HLD \\
\hline RJ083/96 & 1996 & New CPV-2a & AAT (Asn) & - & GTA (Val) & G & V, A, L, HLD \\
\hline RJ126/97 & 1997 & New CPV-2a & AAT (Asn) & - & GTA (Val) & G & V, A, L, HLD \\
\hline RJ129/97 & 1997 & New CPV-2a & AAT (Asn) & - & GTA (Val) & $\mathrm{G}$ & V, A, L, HLD \\
\hline RJ164/98 & 1998 & New CPV-2a & AAT (Asn) & - & GTA (Val) & $\mathrm{G}$ & V, A, L, HLD \\
\hline RJ167/98 & 1998 & New CPV-2a & AAT (Asn) & - & GTA (Val) & A & V, A, L, HLD \\
\hline RJ183/99 & 1999 & New CPV-2a & AAT (Asn) & - & GTA (Val) & A & $\mathrm{V}, \mathrm{A}, \mathrm{L}, \mathrm{LD}$ \\
\hline RJ223/99 & 1999 & New CPV-2a & AAT (Asn) & - & GTA (Val) & $\mathrm{G}$ & V, A, L, HLD \\
\hline RJ251/00 & 2000 & New CPV-2a & AAT (Asn) & - & GTA (Val) & A & $\mathrm{V}, \mathrm{A}, \mathrm{L}, \mathrm{HLD}$ \\
\hline RJ305/01 & 2001 & New CPV-2a & AAT (Asn) & - & GTA (Val) & A & $\mathrm{V}, \mathrm{A}, \mathrm{L}, \mathrm{HLD}$ \\
\hline RJ369/02 & 2002 & New CPV-2a & AAT (Asn) & - & GTA (Val) & A & V, A, L, HLD \\
\hline RJ426/03 & 2003 & New CPV-2a & AAT (Asn) & - & GTA (Val) & A & V, A, L, HLD \\
\hline RJ542/04 & 2004 & CPV-2b & GAT (Asp) & A & GTA (Val) & A & $\mathrm{V}, \mathrm{A}, \mathrm{L}, \mathrm{SD}$ \\
\hline RJ596/04 & 2004 & CPV-2b & GAT (Asp) & A & GTA (Val) & A & V, A, L, HLD \\
\hline RJ630/05 & 2005 & CPV-2b & GAT (Asp) & A & GTA (Val) & A & LD \\
\hline RJ708/06 & 2006 & New CPV-2a & AAT (Asn) & - & GTA (Val) & $\mathrm{A}$ & V, A, L, HLD \\
\hline RJ736/06 & 2006 & New CPV-2a & AAT (Asn) & - & GTA (Val) & A & V, A, L, HLD \\
\hline RJ738/06 & 2006 & New CPV-2a & AAT (Asn) & - & GTA (Val) & G & $\mathrm{V}, \mathrm{A}, \mathrm{L}, \mathrm{SD}$ \\
\hline RJ803/06 & 2006 & New CPV-2a & AAT (Asn) & - & GTA (Val) & G & V, A, L, HLD \\
\hline RJ814/06 & 2006 & CPV-2b & GAT (Asp) & - & GTA (Val) & A & $\mathrm{V}, \mathrm{A}, \mathrm{L}, \mathrm{HLD}$ \\
\hline RJ815/07 & 2007 & CPV-2b & GAT (Asp) & - & GTA (Val) & A & V, A, HLD \\
\hline RJ818/07 & 2007 & CPV-2b & GAT (Asp) & A & GTA (Val) & $\mathrm{A}$ & $\mathrm{V}, \mathrm{A}, \mathrm{L}, \mathrm{LD}$ \\
\hline RJ825/07 & 2007 & CPV-2b & GAT (Asp) & - & GTA (Val) & A & V, A, L, HLD \\
\hline RJ868/08 & 2008 & New CPV-2a & AAT (Asn) & A & GTA (Val) & G & V, A, L, HLD \\
\hline RJ893/08 & 2008 & New CPV-2a & AAT (Asn) & A & GTA (Val) & G & $\mathrm{V}, \mathrm{A}, \mathrm{L}, \mathrm{LD}$ \\
\hline RJ898/08 & 2008 & CPV-2b & GAT (Asp) & A & GTA (Val) & A & V, A, L, HLD \\
\hline RJ913/08 & 2008 & CPV-2b & GAT (Asp) & - & GTA (Val) & G & V, A, L, HLD \\
\hline RJ925/08 & 2008 & $\mathrm{CPV}-2 \mathrm{~b}$ & GAT (Asp) & A & GTA (Val) & A & $\mathrm{V}, \mathrm{A}, \mathrm{L}, \mathrm{HLD}$ \\
\hline RJ926/08 & 2008 & CPV-2b & GAT (Asp) & A & GTA (Val) & $\mathrm{A}$ & V, A, L, HLD \\
\hline RJ933/08 & 2008 & CPV-2b & GAT (Asp) & A & GTA (Val) & G & A, L, HLD \\
\hline RJ934/08 & 2008 & CPV-2c & GAA (Glu) & A & GTA (Val) & $\mathrm{A}$ & $\mathrm{V}, \mathrm{A}, \mathrm{L}, \mathrm{SD}$ \\
\hline RJ944/09 & 2009 & $\mathrm{CPV}-2 \mathrm{~b}$ & GAT (Asp) & A & GTA (Val) & $\mathrm{G}$ & $\mathrm{V}, \mathrm{A}, \mathrm{L}, \mathrm{LD}$ \\
\hline
\end{tabular}


All samples $(n=12)$ collected from 1995 to 2003 were characterized as CPV-2a. From 2004 to 2006, both CPV-2a (4/8) and CPV-2b (4/8) were detected. After 2006, most samples tested positive for CPV-2b (10/12), and only two samples tested positive for CPV-2a. All of the CPV-2a strains detected in this study had a $G$ at nt position 4449 , which results in Val-555 and types these isolates as "new CPV-2a".

Nineteen of the 32 samples collected throughout the study period had a synonymous substitution of $A \rightarrow G$ at position 4508, which has not been previously observed in Brazil. An additional synonymous mutation, an insertion of an $\mathrm{A}$ at $\mathrm{nt}$ 4104 (residue 440), was observed in $75 \%$ of the CPV-2b strains (9/12), in $10.5 \%$ of the "new CPV-2a" (2/19) strains, and in the CPV-2c strain.

The classical signs of CPV enteritis (vomiting, anorexia, lethargy and hemorrhagic fluid diarrhea) were observed in $66 \%$ of the sampled puppies (21/32) (16 "new CPV-2a" and 5 CPV-2b). For 10 sampled puppies (3 "new CPV-2a" and 7 CPV-2b), the association with clinical signs varied, and the only CPV-2c puppy presented mild clinical signs (vomiting, anorexia, lethargy, and soft diarrhea).

\section{DISCUSSION}

This study represents the first report of the new type of CPV-2c in the state of Rio de Janeiro, Brazil. This variant was also detected in Argentina in 2003 (3), in Uruguay in 2007 (23), and in the Southern region of Brazil in 2008 (24). The detection of this new variant in Argentina and Uruguay (southern border) along with its detection in Rio de Janeiro (Southeast Brazil) supports the idea that CPV-2c is quickly expanding and reaching a wide distribution, as occurred with the other antigenic types, "new $2 \mathrm{a}$ " and $2 \mathrm{~b}$.

The low number of single nt substitutions found in the type 2c CPV strains in South America reinforces the hypothesis that there is a low level of variability among the type 2c CPVs from different parts of the world (10).

A Brazilian study conducted with samples collected from 1980 to 2000 (22) showed the presence of the "new CPV-2a" and 2b types co-circulating from 1980 until 1986. After 1990, all of the CPV strains were characterized as "new CPV-2a" and type $2 b$ were no longer detected. In our study, the analysis of CPV strains from 1995 to 2009 showed the reappearance of CPV-2b in the canine population after 2004. As also reported in other studies, only the "new CPV-2a" strains have been circulating in Rio de Janeiro, suggesting an antigenic evolution of this new type $(2,11)$.

In many ways, the epidemiological history of CPV in Brazil resembles those seen in other countries due to a constant process of rapid antigenic-type replacement by more adaptaded strains and the evolution of viral strains over time $(9,22,19)$. The reasons for the type distribution could be related to replicative advantages in the host cell or to more efficient virus shedding in the feces.

Non-synonymous and synonymous mutations at residue 440 (nt 4104) have been described in CPV strains isolated from other countries, such as Italy (1), the United States (13, 14), and Korea (18), and in two CPV-2a Brazilian strains collected in 1993 and 2002 (22).

In this study, a synonymous mutation (an A insertion) at residue 440 was observed in stool samples collected after 2004. This residue is located on an exposed region at the surface of the viral capsid, and a greater variability between parvoviruses has been observed in this antigenic region (1). Another synonymous mutation at residue 574 (an A-G substitution at nt 5408) was detected in both $2 \mathrm{a}$ and $2 \mathrm{~b}$ CPV types after 1998, and changes in this residue have not been previously described. The exact phenotypic consequence of this mutation is not clear, but it has been sustained in the canine population since 1998 and may represent a local adaptation of CPV strains.

The onset of clinical signs that are similar to those of canine parvovirus (anorexia, lethargy, vomiting, and hemorrhagic fluid diarrhea) is a frequent finding in veterinary practice $(4,11,18)$. The field pathogenicity of the new strain, CPV-2c, has been investigated, and most of the CPV-2c cases reported had clinical signs associated with severe hemorrhagic enteritis, in some cases resulting in a fatal outcome $(8,14)$. 
However, the CPV-2c strain detected in this study was collected from a puppy with mild clinical signs.

Studies that investigated the pathogenicity of the other variants ("new CPV- 2a" and 2b) also showed conflicting results. There are some reports suggesting that CPV-2b may cause a milder disease than CPV-2a viruses $(17,18)$; however, both CPV-2a and $2 \mathrm{~b}$ have been detected in animals with severe diarrhea (14). Although the main purpose of this study was the genomic typing of CPV strains circulating in Rio de Janeiro, it should be noted that most of the "new CPV-2a" samples $(16 / 19)$ were collected from puppies with a more severe enteric disease.

Our results demonstrate that, despite its DNA genome, CPV shows continuous genetic diversity and a rapid displacement of old types by new antigenic variants. For this reason, continuous epidemiological surveillance of the distribution of CPV strains is essential to studying the patterns of spread for CPV-2a and $2 \mathrm{~b}$ and to elucidate whether the new variant, CPV-2c, has become permanently established in the canine population in Brazil. This study provide insights into the mechanisms involved in the evolution of CPV and may represent an opportunity to investigate the ability of this DNA virus to adapt and evolve in its natural host population.

\section{ACKNOWLEDGMENTS}

This study was supported by the "Conselho Nacional de Desenvolvimento Científico e Tecnológico" (CNPq), by the "Universidade Federal Fluminense- Pró-Reitoria de Pesquisa e Pós-Graduação" (UFF-PROPP), by the "Fundação de Amparo à Pesquisa Carlos Chagas Filho" (FAPERJ), and "Instituto Oswaldo Cruz - Fundação Oswaldo Cruz” (IOC-FIOCRUZ). Tatiana X. Castro is a fellowship recipient of "Coordenação de Aperfeiçoamento de Pessoal de Nível Superior" (CAPES) for participating in the Graduate Program of the Faculty of Veterinary Medicine, "Universidade Federal Fluminense”. We also thank Dr. Marcelo de Lima for the critical revision and helpful discussion of the manuscript.

\section{REFERENCES}

1. Battilani, M.; Ciulli, S.; Tisato, E.; Prosperi, S. (2002). Genetic analysis of canine parvovirus isolates (CPV-2) from dogs in Italy. Virus Res. 83, $149-157$.

2. Buonavoglia, C.; Martella, V.; Pratelli, A.; Tempesta, M.; Cavalli, A.; Greco, G.; Buonavoglia, D. (2001). Evidence for evolution of canine parvovirus type 2 in Italy. J. Gen. Virol. 82, 3021-3025.

3. Calderon, M.G.; Mattion, N.; Bucafusco, D.; Fogel, F.; Remorini, P.; La Torre, J. (2009). Molecular Characterization of Canine Parvovirus strains in Argentina: Detection of pathogenic variant CPV 2c in vaccinated dogs. J. Virol. Methods. 159(2), 141-145.

4. Castro, T.X.; Miranda, S.C.; Labarthe, N.V.; Silva, L.E.; Cubel Garcia, R.C.N. (2007). Clinical and epidemiologocal aspects of canine parvovitus (CPV) enteritis in the State of Rio de Janeiro: 1995- 2004. Arq. Bras. Med. Vet. Zootec. 59 (2), 333-339.

5. Costa, A.P.; Leite, J.P.G.; Labarthe, N.V.; Cubel Garcia, R. C. N. (2005). Genomic typing of canine parvovirus circulating in the State of Rio de Janeiro, Brazil from 1995 to 2001 using polymerase chain reaction assay. (2005). Vet. Res. Commun. 29(8), 735-743.

6. Cubel Garcia, R.C.N.; Pinto, A.; Costa, A.; Maciel, B.M.; Oliveira, L.H.S.; Nascimento, J.P.; Santos, A.O.; Castro, M.C.N.; Willi, L.M.V.; Labarthe, N.V. (2000). Canine parvovirus infection in puppies with gastroenteritis in Niterói, Rio de Janeiro, from 1995 to 1997. Braz. J. Vet. Res. Anim. Sci., [Periodico on line]. 37(2), 132-135.

7. Cubel Garcia, R.C.N.; Leite, J.P.G.; Xavier, M.P.T.P.; Willi, L.M.V.; Lemos, M.C.; Castro, T.X.; Mertens, R.; Labarthe, N.V. (2002). Infecção pelo parvovírus canino no Rio de Janeiro: Um Estudo de 5 anos. Rev. Bras. Cien. Vet. 9(1), 42-46.

8. Decaro, N; Martella, V.; Desario, C.; Bellacicco, A. L.; Camero, M.; Manna, L.; D’Aloja, D.; Buonavoglia, C.(2006). First detection of canine parvovirus type $\mathrm{C}$ in pups with haemorragica enteritis in Spain. J. Vet. Med. 53, 468-472.

9. Decaro, N.; Desario, C.; Addie, D.; Martella, V.; Vieira, M.; Elia, G.; Zicola, A.; Davis, C.; Thompson, G.; Thiery, E.; Truyen, U.; Buonavoglia,C. (2007). Molecular epidemiology of canine parvovirus, Europe. Emerg. Infect. Dis. 13(8), 1222-1224.

10. Decaro, N.; Desario, C.; Parisi, A.; Martella, V.; Lorusso, A.; Micopullo, A.; Mari, V.; Colaianni, M. L.; Cavalli, A.; Di Trani, L.; Buonavoglia, C. (2009). Genetic analysis of canine parvovirus type 2c. Virology 385, 510.

11. Desario, C.; Decaro, N.; Campolo, M.; Cavalli, A; Cirone, F.; Elia, G.; Martella, V.; Lorusso, E.; Camero, M.; Buonavoglia, C. (2005). Canine Parvovirus infection: Wich diagnostic test for vírus? J. Virol. Met. 126, 179-185.

12. Homem, V.S.F.; Mendes, Y.G.; Linhares, A.C. (1999). Gastroenterite canina-agentes virais nas fezes de cães diarreicos e não diarreicos. Arq. 
Bras. Med. Vet. Zootec. 51:531-536.

13. Hong, C.; Decaro, N.; Desario, C.; Tanner, P.; Pardo, M.; Sanchez, S.; Buonavoglia, C.; Saliki, J.(2007). Occurrence of canine parvovirus type $\mathrm{C}$ in the United States. J. Vet. Diagn. Invest. 19, 535-539.

14. Kapil, S.; Cooper, E.; Lamm, C.; Murray, B.; Rezabek, G.; Johnston III, L.; Campbell, G.; Johnson, B. (2007). Canine parvovirus types $2 \mathrm{~b}$ and 2c circulating in North American dogs in 2006 and 2007. J. Clin. Microbiol. 45(12), 4044-4047.

15. Larson, L.; Schultz, R. (2008). Do two current canine parvovirus type 2 and $2 \mathrm{~b}$ vaccines provide protection against the new type $2 \mathrm{c}$ variant? Vet. Ther. 9(2), 94-101.

16. Martella, V.; Decaro, N.; Elia, G.; Buonavoglia, C. (2005). Surveillance activity for canine parvovirus in Italy. J. Vet. Med. 52, 312-315.

17. Meers, J.; Kyaw-Tanner, M.; Benzink, Z.; Zwijnenberg, R. (2007). Genetic analysis of canine parvovirus from dogs in Australia. Aust. Vet. J. 85(10), 392-396.

18. Moon, H-S.; Lee, S-G.; Choi, R.; Jeoung, S-Y.; Kim, D.; Hyun, C. (2008). Comparison of the pathogenicity in three different Korean canine parvovirus 2 (CPV-2) isolates. Vet. Microbiol. 131(1-2), 47-56.

19. Ohshima, T.; Hisaka, M.; Kawakami, K.; Kishi, M.; Tohya, Y.; Mochizuki, M. (2008). Chronological analysis of canine parvovirus type 2 isolates in Japan. J. Vet. Med. Sci. 70(8), 769-775.

20. Otto, T.D.; Vasconcellos, E.A.; Gomes, L.H.F.; Moreira, A.S.; Degrave, W.M.; Mendonça-Lima, L.; Alves-Ferreira, M. (2008). ChromaPipe: a pipeline for analysis, quality control and management for a DNA sequencing facility. Gen. Mol. Res. 7(3)861-871.

21. Parrish, C.; Aquadro, C.; Strassheim, M.; Evermann. J.; Sgro, J.; Mohammed, H. (1991). Rapid antigenic-type replacement and DNA sequence evolution of canine parvovirus. J. Virol. 65(12), 6544-6552.

22. Pereira, C.; Leal, E.; Durigon, E. (2007). Selective regimen shift and demographic growth increase associated with the emergence of hightfitness variants of canine parvovirus. Infect. Gen. Evol. 7, 399-409.

23. Pérez, R.; Francia, L.; Romero, V.; Maya, L.; López, I.; Hernández, M. (2007). First detection of canine parvovirus type C in South América. Vet. Microbiol.124, 147-152.

24. Rodendusch, C.; Souza, C.; Gonçalves, K.; Streck, A.; Canal, C. (2008). Detection of canine parvovirus type 2c in Brazil. XIX National Meeting of Virology, Caxambú, MG, Brazil, p.272.

25. Senda, M.; Parrish, C.; Hirasawa, R. (1995). Detection by PCR of wildtype canine parvovirus which contaminates dog vaccines. J. Clin. Microbio. 33 (1),110-113.

26. Truyen, U.; Everman, J.F.; Vister, E.; Parrish, C.R. (1996). Evolution of canine parvovirus involved loss and gains of feline host range. Virology 215, 186-189.

27. Vieira, M.; Silva, E.; Oliveira, J.; Vieira, A.; Decaro, N.; Desario, C.; Muller, A.; Carvalheira, J.; Buonavoglia, C.; Thompson, G. (2008). Canine parvovirus $2 \mathrm{c}$ infection in central Portugal. J. Vet. Diag. Invest. 20, 488-491. 